\title{
A ESCOLARIZAÇÃO DE CRIANÇAS PSICÓTICAS
}

\author{
Alfredo Jerusalinsky
}

\begin{abstract}
"De que se trata quando falo de Verwerfung?
Trata-se do rechaço, da expulsão, de um significante primordial para as trevas exteriores, significante que a partir de entāo faltará nesse nivel. Esse é o mecanismo fundamental que suponho está na base da paranóia. Trata-se de um processo primordial de exclusão de um interior primitivo, que não é o interior do corpo, mas o interior de um primeiro corpo de significantes."
\end{abstract}

(Lacan, 1981, p.217)

D crianças psicóticas? Evidentemente, embora de um modo interrogativo, estamos fazendo uma afirmação: deve haver escolas para psicóticos. Isso quer dizer que não consideramos suficiente que existam hospitais-dia, instituições de internação parcial ou total, ou mesmo consultórios para tratamentos ambulatoriais 1 .

É necessário que existam escolas. Por que? Há pelo menos três razões. A primeira é a que se refere às condições de aprendizagem ou às aprendizagens dos psicóticos. A segunda, é a que se refere ao fato de que na infância a psicose, numa proporção muito significativa, não está ainda totalmente decidida, ou seja, numa proporção muito signi- ficativa, nas crianças psicóticas, a psicose é indecidida. Aliás, é uma classificação que estamos propondo: psicoses indecididas como uma forma típica das psicoses na infância. Diferentemente do que acontece no sujeito adulto em quem não há psicoses indecididas, essa parece ser uma formação psicopatológica própria da infância.

Diziamos, então, que há uma primeira razão relativa às aprendizagens dos psicóticos. Uma segunda razão, ou um segundo grupo de razões, a respeito da não decisão ainda da psicotização definitiva. E uma terceira razão de ordem social, que não por ser social é de menor importância para o sujeito psicótico individualmente considerado.

Psicanalista Membro da Associação Psicanalítica de Porto Alegre, e da Association Freudienne Internationale. Diretor do Centro "Lydia Coriat" de Porto Alegre e de Buenos Aires 


\section{SINCRONIA E DIACRONIA. O INATO E O ADQUIRIDO}

Vejamos o primeiro grupo de razões. É sabido que a constitução do sujeito psíquico leva tempo mas não sabemos quanto, não há modo de sabermos a priori até porque o tempo requerido é mais de ordem lógica que cronológica. Estamos nos referindo à sincronia da estruturação, ou seja, ao fato de que a estruturação psíquica se produz pela incidência sincrônica da maior extensão da cadeia significante, ou seja, do modo em que está organizado o discurso para marcar a uma determinada criança na sua posição de sujeito; isso acontece de um modo sincrônico. Poderíamos dizer que todos os pontos da cadeia significante, o modo como ela está organizada em termos de discurso, tocam ao mesmo tempo a essa criança ainda que a toquem somente em um ponto. Esse ponto de enodamento ou de capiton - suporta todo o peso de cada uma das intersecções virtualmente possíveis entre a cadeia significante e o discurso, na medida em que em cada ato do dizer os pais e os que rodeiam a criança atualizam passado e futuro, inscrevendo no presente a filiação e o ideal aos quais se espera que a criança responda. Se bem que isso é assim, ou seja, sincrônico, é necessário o tempo diacrônico dos efeitos significantes para que essa estrutura se consolide, se coloque à prova e adquira sua versão singular. Este enunciado que acabamos de formular apresenta ainda muitos pontos escuros porque certamente é uma formulação extremamente condensada de um problema complexo como é a estruturação do sujeito. Mas, na tentativa de esclarecer alguns desses pontos, vamos nos deter mais um pouco nesta questão da sincronia e da diacronia.

É um problema antigo na psicologia e na psicanálise este paradoxo, esta oposição, este confronto entre a sincronia e a diacronia. Sabe-se que esta questão é quase tão antiga quanto a psicologia contemporânea ou a psicologia moderna e, sem dúvida, tão antiga quanto a psicanálise. Trata-se da problemática conjugação entre a evolução da criança e a inscrição da posição do sujeito que nela fala. Por exemplo, a oposição entre uma psicologia evolutiva e uma psicologia genética, tomando-a em sua versão mais apurada que é a piagetiana. Evidentemente, para J. Piaget, se há uma diacronia construtiva no desdobramento das estruturas cognitivas, as condições para esse desdobramento estão sincronicamente inscritas desde o começo da vida. Isso é que ele chama de invariantes, as invariantes organizacionais e as invariantes funcionais, ou seja, as invariantes estruturais e as invariantes funcionais. Este assunto vamos tomá-lo somente como uma ilustração desta questão da oposição na psicologia entre a sincronia e a diacronia .

Piaget (1969) diz que o funcionamento mental está organiza- 
do de um modo analógico ao funcionamento biológico, ou seja, é análogo, segue os mesmos princípios lógicos, pelo menos no seu fundamento. Então ele diz que todos os organismos vivos têm de um lado algumas invariantes. Invariantes quer dizer não exatamente constantes, mas formas de funcionar sempre iguais. Não como uma constante que seria um multiplicador único, mas uma invariante, uma forma de funcionar que não varia. Podem variar tanto seu valor quanto seu resultado, mas a forma de funcionar, não.

Assim, por exemplo, ele diferencia dois grupos de igual hierarquía. Um, que são as invariantes estruturais e outro, que são as invariantes funcionais. As invariantes organizacionais ou estruturais consistem, como ponto de parti$\mathrm{da}$, no seguinte princípio que afeta a toda matéria viva: toda matéria viva tem algum modo de organização de seus intercâmbios com o meio,ou seja, não é que a organização do intercâmbio seja sempre a mesma, mas sempre há alguma forma de organização.

Nos seres humanos há uma forma de organização também. Essa forma de organização se caracteriza por três estruturas lógicas. A do grupo prático de deslocamentos, a dos oito agrupamentos lógicos e as estruturas do grupo lógico das quatro transformações ou a rede de transformações. São três estruturas lógicas analisadas pelos matemáti$\cos$, oriundas da teoria do grupo matemático dos Bourbakis. Jean Piaget diz que o fato de que os Bourbakis encontraram, que os matemáticos encontraram, nas suas pesquisas sobre lógica matemática, o mesmo que ele encontrou nas suas pesquisas sobre o pensamento da criança, não é por acaso. Eles encontraram o que funciona assim. Essas relações lógicas que eles encontraram, que estão expressas e formalizadas na matemática, eles as descobri- ram, não são um invento mas uma descoberta, porque as coisas funcionam assim. Este é o critério de Piaget e, por sinal, o critério dos estruturalistas 2 .

Hoje em dia, isso está em discussão a partir fundamentalmente dos teóricos do acontecimento, ou seja, os que introduzem uma dúvida radical nesta determinação funcional interrogando-a a cerca de que papel tem o acaso, se a determinação é do lado do acaso e nào do lado da estrutura pré-formada ${ }^{3}$.

Piaget, no entanto, tem esse ponto de vista estritamente estruturalista de que há uma estrutura pré-formada para ordenar, organizar o modo de funcionamento mental a respeito dos intercâmbios com o meio 4 .

As invariantes funcionais, ele diz, são duas: assimilação e acomodação. $\mathrm{O}$ princípio fundamental da invariante funcional é de que todo organismo vivo cumpre funções adaptativas, ou seja, tem que realizar algum trabalho para se adaptar ao meio. O trabalho que realiza tem duas direções: uma, transformando o meio para adequá-lo à estrutura interna e outra, transformando a estrutura interna para adequá-la ao meio. A criatura nasce com essa forma de funcionar, ou seja, isso é sincrônico; embora os efeitos, as conseqüências desse funcionamento se desdobrem numa diacronia, a forma de funcionar mesma não vai se adquirindo aos poucos. Ele pensa que isso é sincrônico e tem razão, isso é sincrônico. Se for assim, é sincrônico.

Agora, por outro lado, ele diz que a esta sincronia, a tudo isto que está dado ao mesmo tempo desde o início e funciona ao mesmo tempo, ou seja, não sucessivamente, ele diz que, em oposição a essa sincronia há processos diacrônicos, ou seja há uma sucessão de estruturas. Ele diz o seguinte: a estrutura do grupo das quatro transformações, a saber, a idêntica, a recíproca, a inversa e a complementar, esse grupo, esse 
sistema de transformações das coisas, a criança não nasce podendo operar desse modo. Porém, no grupo prático de deslocamentos já está contido - no nível de uma lógica prática - o grupo das quatro transformações - que se constitui no nível de uma lógica do possível -, ou seja, há uma certa sincronia. Está contido no sentido de que se o grupo prático de deslocamentos, que também curiosamente não opera por quatro, mas por pares que dão oito transformações, ou seja, são quatro pares, se este grupo prático de deslocamento funciona mal, vai funcionar mal, (estamos simplificando um pouco), o grupo das quatro transformações.

O grupo prático de deslocamentos é dos primeros dois anos de vida; os agrupamentos lógicos se constroem desde os três até os onze e dos onze, doze, treze em diante, mais ou menos, o grupo das quatro transformações. $\mathrm{Ou}$ seja, também há uma diacronia, porém, se o último agrupamento já está contido no primeiro, o fato de ele funcionar de modo autônomo a respeito do modo prático do primeiro requer um desdobramento da experiência no tempo. Esta formalização piagetiana do sincrônico e do diacrônico é a forma mais acabada das inúmeras formas de desdobramento que esta contradição entre o adquirido e o inato atravessou no campo da psicologia.O quanto de inato há já formado na criança e o quanto é adquirido constitui uma oposição entre diacronia e sincronia.

Poderíamos, talvez, situar o início desta discussão em Charles R. Darwin, ou seja, com as observações de Darwin sobre as diferenças individuais ${ }^{5}$. É sabido que Darwin, além de ser o autor da teoria da evolução, era um pensador filosófico-científico que pretendia estender esta teoria, como todo grande descobridor, a outros fenômenos da cultura e da natureza humana ${ }^{6}$. É por isso que ele fez algumas observações sobre as diferenças individuais nos seus filhos e as confrontou com a teoria da evolução. Há textos de Darwin de certo interesse histórico sobre esta questão.

Esta controvérsia, esta oposição entre a sincronia e a diacronia é quase tão antiga quanto a psicologia e certamente, sem dúvida, tão antiga quanto a psicanálise. Controvérsia inevitável porque, na verdade, esta contraposição entre sincronia e diacronia é própria dos fenômenos humanos por essa capacidade que temos os humanos de anteciparmo-nos no tempo, anteciparmo-nos aos acontecimentos no nível reflexivo ou conservar como presentes episódios do passado. Então essa oposição entre diacronia, entre historicidade e sincronicidade é própria do funcionamento humano. Esta contradição ou este modo paradoxal que temos de funcionar no presente mas no passado, no passado mas no futuro, no futuro mas no presente, este modo paradoxal que temos de funcionar, inevitável para nós, tem adotado formas de controvérsia. Essa é a razão de terem aparecido, na história da psicologia e da psicanálise, escolas evolutivistas ou teorias evolutivas que adotam o ponto de vista de que tudo é uma aquisição progressiva diacrônica, e outros pontos de vista que adotam a perspectiva de que tudo é sincrônico.

\section{SINCRONIA E DIACRONIA NO DISCURSO. \\ A HERANÇA COMO METÁFORA.}

Porém, sincrônico não é sempre, nem na psicologia nem na psicanálise, sinônimo de inato. Por exemplo Lacan e Freud, de duas maneiras diferentes, elaboraram respectivas teorias de sincronicidade da inscrição do sujeito ou 
da produção da estrutura fundamental do sujeito de um ponto de vista não inatista. Ao mesmo tempo, com seus estudos sobre a estrutura e o funcionamento da pulsão, sobre a temporalidade do inconsciente, e sobre a lógica do significante, conseguiram esclarecer pontos cruciais dessa impasse entre o diacrônico e o sincrônico, ou suas formas reducionistas de inato e adquirido. Sobretudo, quando colocam os termos da herança no seu duplo sentido biológico e metafórico ${ }^{7}$.

Por este caminho, chegamos mais longe do que tínhamos nos proposto inicialmente, mas provavelmente deste modo fique melhor ilustrada a problemática da sincronia e a diacronia.

Falar, esse ato tão simples de falar, também padece do mesmo paradoxo da articulação entre diacronia e sincronia. A diacronia, é fácil percebê-la porque não temos outra possibilidade do que pronunciar uma palavra depois da outra, portanto falar é inevitavelmente um fenômeno diacrônico. Mas nós bem sabemos que nada na cadeia significante que vamos pronunciando está desvinculado do que anteriormente dissemos ou do que depois iremos dizer. Tanto que é isso que nos permite guardar a correspondência de gênero, número, as correspondências sintáticas, sem falar das correspondências paradigmáticas, ou seja, de sentido arbitrário. No que vamos dizendo, cada palavra, embora pronunciada diacronicamente em relação às outras, do ponto de vista lógico está intrinsecamente relacionada sincronicamente com seus antecedentes e seus consequentes. Quer dizer que no momento em que pronunciamos uma palavra está presente nela o que já dissemos antes e o que vamos dizer depois. Se assim não fosse, como fariamos para conservar correspondência de gênero e número, as correspondências sintáticas em geral e, sobretudo, a correspondência recíproca entre significantes relativos ao sentido do que pretendemos dizer?

Todos os fenômenos humanos padecem desse paradoxo. É por isso que, a cada coisa que formos dizer, fica inconscientemente formulada a dúvida de se deveríamos ou não dizê-la, pelas consequências que podería provocar $\mathrm{O}$ ato de dizer ou não dizer tal coisa, em função do sentido que advirá. Assim, por exemplo, há frases nas quais a supressão do último termo modifica tão evidentemente o significado de todo o anterior, que se precipita ali um sentido ora cômico ora trágico, sentido do qual o sujeito dificilmente consegue se furtar. Por exemplo, suprimindo a cada vez a última palavra temos:

Jamais a vi com outro vestido senão o da pele arrancada daquele animal.

Jamais a vi com outro vestido senão o da pele arrancada daquele.

Jamais a vi com outro vestido senão o da pele arrancada.

Jamais a vi com outro vestido senão o da pele.

Jamais a vi com outro vestido senão... Jamais a vi com outro vestido.

Jamais a vi com outro.

Jamais a vi.

Jamais.

Esse exercício pode ser feito com qualquer texto. $\mathrm{O}$ que demonstra que estamos incessantemente confrontados com uma articulação nada pacífica entre a sincronia e a diacronia de nossa própria estrutura enquanto sujeitos.

É fácil então supor, e quem assim o faz tem toda a razão, que quando não há articulação entre o sincrônico e o diacrônico as coisas andam mal, algo não funciona, e as consequências costumam ser sérias.

Quando uma criança recebe algo da ordem de uma inscrição, as consequências do modo como isso se produz vão se estender por todo o seu futuro, 
consequências que podem ser mais espetaculares, mais graves, mais visíveis ou mais sutis, mas que vão se estender por toda a sua vida. O que não quer dizer que o tipo de marca que nós estamos chamando de inscrição consista numa predestinação. Não há predestinação no ser humano, não estamos predestinados a nada - ou, para sermos mais precisos, estamos predestinados ao nada - justamente este é o nosso problema. Se estivéssemos predestinados a algo, se realmente acreditássemos nas teorias de predestinação das quais já se elaboraram muitas e que tiveram muitos adeptos, pela simples razão de que é uma grande necessidade humana que alguém nos resolva o destino - nossas preocupações ficariam reduzidas ao mínimo. Por sorte ou desgraça, todos os que acreditaram e aderiram a essas teorias de predestinação não acreditaram o suficiente para por-se a dormir, quer dizer," se estou predestinado, não faço nada, as coisas vão acontecer de todo modo". Ninguém acreditou o suficiente nessa teoria da predestinação, nem sequer os gregos, para adotar essa postura de passividade absoluta. $\mathrm{Na}$ verdade, devemos dizer que alguns andaram muito próximo, as formas extremas e mais iniciais do budismo andaram muito perto. De fato algumas formas das religiões brahamânicas hinduístas mais antigas andaram perto. Geralmente, no nascimento das religiões, as teorias de predestinação têm mais força, justamente porque um novo deus sempre oferece a esperança de que, de uma vez por todas, tenha aparecido aquele que resolve nosso destino. Mas com o decorrer da história essa função dos deuses vai-se debilitando 8

Este conjunto de considerações iniciais acerca do sincrônico e o diacrônico, do inato e do adquirido, constituem o debate geral no qual se situa a questão das incrições primordiais. Aquelas que vão inaugurar a possibilidade da constituição de um sujeito no filhote humano. Entre a teologia e a biología, a psicanálise destaca o valor discursivo dessas inscrições. É necessário compreendermos esses vetores extremos das manifestações da cultura para tentar desfazer as concepções ora mítico-científicas ora mítico-religiosas das psicosis, e assim termos alguma chance de situar ao sujeito face à articulação simbólico-real que o determina nessa posição impossível.

\section{A INSCRIÇÃO DOS SIGNIFICANTES PRIMORDIAIS}

Então a quê denominamos inscrição? Conceito fundamental para quem tenta entender alguma coisa a respeito das psicoses e do autismo infantil. Comecemos por assinalar que estamos nos referindo àqueles significantes primordiais constituintes de um primeiro corpo, como assinala J. Lacan na citação de nossa epígrafe.

Uma inscrição ocorre quando uma mãe diz não. Ao ponto de que se uma mãe não diz não, não há inscrição. Estamos formulan- 
do a questão deste modo tão simples, para que não nos escape a idéia fundamental. É claro, nessa frase, mamãe não é a mamãe de carne e osso mas aquele agente que se encarrega de colocar em ato isso que se chama discurso materno. É claro, também, que o bebê não compreende em absoluto a extensão desse não, mas padece de um modo sideral das conseqüências dessa negativa. A que denominanos, então, discurso materno? O discurso materno é aquele que opera a palavra de um modo tal que a torna capaz de recortar o corpo da criança em pedacinhos, que lhe tira e "entressaca" pedaços. É claro, há maneiras mais cruéis e mais contemplativas de fazer isso, há maneiras simbólicas de fazer isso ou maneiras reais.

Não estranhem quando falamos de 'maneiras reais' porque há, por exemplo, um caso extremo relatado por Jean Bergès que ilustra esse modo real de produzir essa extração de pedaços, esse recorte. Esse caso ocorreu quando uma mãe psicótica fez um buraco com uma faca no crânio de seu bebê. Curiosamente este buraco para ela teve um efeito 'normalizante' porque ela cumpriu a sua função. É claro, a criança morreu, obviamente, mas ela experimentou culpa. Ou seja, ela entrou no campo da castração, solicitou castigo por seu ato e foi castigada. Cumpriu a prisão e saiu de lá funcionando de um modo socialmente relativamente "normal". Evidentemente tão psicótica quanto antes, mas estabeleceu através deste ato sua simbolização da culpa e do castigo com uma metáfora que lhe serviu de referência possivelmente pelo resto da vida. Continuou trabalhando, circulando socialmente, sob vigilância. Já que ela foi parar, obviamente, em um hospital psiquiátrico regido pelo sistema penal, um instituto psiquiátrico forense, e seguramente suas saídas periódicas foram autorizadas quando se comprovou que não havia risco de periculosidade. Mas sempre foi uma vida, digamos, vigiada 9

Mencionamos este exemplo para que fique em evidência como o discurso materno pode atravessar vicissitudes e operações das mais estranhas. Quem trabalha com crianças com problemas graves sabe que o discurso materno pode atravessar momentos de crueldade impensáveis até nas maiores neuróticas.

Temos até aqui, então, que o discurso materno é aquele que se exerce sob a forma de recortar o corpo da criança, recorte que se opera dizendo não a esses pequenos objetos cuja extração, cuja separação, será capaz de um modo imediato e direto de provocar um esvaziamento ou uma falta. Discurso materno que é geralmente muito mais exequivel para a mulher, porque se os homens são especialistas em prometer o que não têm (o falo), as mulheres são especialistas em não dar o que têm (que obviamente não é o falo, mas o real de seu corpo, que, no ato de negá-lo, se torna fálico). Por essa razão, as mulheres instaladas do lado da feminilidade exercem com muito maior comodidade isso que se chama o discurso materno, por isso os homens estão sempre mais inclinados a 
prometer e, por isso, exercem este discurso de um modo muito mais trabalhoso quando se vêem obrigados pelas circunstâncias a exercê-lo. O discurso materno, precisamente, é aquele que diz não ao cocô, "cocô não", ou seja a instalação do controle esfincteriano, "xixi não", "peito não", "olhar não". É por isso que esses pequenos objetos as fezes, os excrementos, o olhar, a voz - se recortam e se destacam. Escutar não, já que tem coisas que a criança não deve ouvir; olhar não, pois o olhar está interditado, sendo o melhor exemplo disso o fato de todos estarmos vestidos.

Somente quando alguém toma a seu cargo dizer não, estes pequenos objetos adquirem a sua relevância. É por isso, precisamente, que as fezes, a voz, o olhar, o peito têm tanta relevância para nós, os humanos. Tanta relevância que quando alguma coisa falha do ponto de vista do funcionamento mental, com bastante precipitação, com muita frequência e muito rapidamente essa falha começa a se exprimir nas dificuldades de manejar esses objetos: se perde o controle esfincteriano, se urina onde não se deve e se fala ou se escuta o que não está aí, se escutam vozes, se vê alucinatoriamente o que não está aí, ou se espreita compulsoriamente o que não se permite ver.

\section{OS PEQUENOS OBJETOS DOS SINTOMAS PSICÓTICOS.}

Estes pequenos objetos, Lacan os chama de objetos pequenos a, recortes que representam o modo que os humanos têm de registrar a falta do objeto. Já que não temos outro, temos esse, precisamos de uma mamãe que nos diga "cocô não", "peito nâo", "olhar não". Então, quando temos uma mãe que nos diz isso, começamos a registrar que algo nos faz falta. E por isso, quando fica restringida a possibilidade de simbolizar essa falta um pouco mais longe que o cocô em si mesmo, que a voz em si mesma, que o peito em si mesmo ou que o olho do outro em si mesmo ${ }^{10}$, quando temos dificuldades de simbolizar isso a uma certa distancia do objeto real, então nos precipitamos na dificuldade de manejar esses objetos no campo do discurso, ou gozamos simplesmente manejando esses objetos tal como eles são. Eis aquí o $\mathrm{ABC}$ da psicopatologia. E se não se procede ao deciframento desse núcleo fundamental da inscrição, a psicose e o autismo vão permanecer no terreno mítico onde as operações de tentativa de cura nada têm a ver com a restituição de um sujeito. E tampouco vai-se entender por que uma criança psicótica brinca com as suas fezes e faz quadrinhos no banheiro, por que um pequeno bebê faz bolhas de saliva, ou a importância de um autista brincar com a sua baba, ou ainda por que os garotos se esforçam em descrever pequenas acrobacias com o jato de urina.

Vejamos a esse respeito uma situação clínica: trata-se de um paciente que começou sua terapia aos quatro anos de idade, e que aos seis anos atravessou uma fase que me obrigava a passar a mangueira no pátio da clínica cada vez que terminava a sessão porque ele encerava o pátio da clínica com o seu cocô. Por sinal a atendente se negava absolutamente a lavar esa sujeira, na medida em que ela não compreendia em absoluto porque que eu suportava isso. Mulher enérgica e decidida, interpretava minha tolerância como um signo de debilidade. Mais ainda, ofereceu-se repetidas vezes para "acabar com essa porqueira em dois toques". Indagada acerca desses "dois Toques", ela os especificava: primeiro chamar a 
mãe para limpar, segundo fazê-lo limpar junto com a mãe. Mal suspeitava a prestativa atendente que meu paciente podia suportar a 'perda' de seu objeto (o cocô) na medida em que esse amplo espaço de acolhimento que a clínica representava ficasse recoberto por ele. Uma equação simples, ainda que malcheirosa: ficar envolvido pelo pedaço de seu corpo que se desprendia dele, já que nenhum outro se constituira ainda como representante desses objetos, nem como seu depositário simbólico. A atendente confiava na sua eficácia pedagógica. Nós sabíamos que o menino, todo ele, representava uma sujeira para seus pais. Essa sujeira operava como seu nome: um ato simbólico que, se fosse tomado como real, eliminaria uma das poucas chances que tínhamos de situar a palavra na dimensão real da pulsão: no seu valor de inscrição no corpo. Por isso, continuamos por alguns meses limpando o pátio com a mangueira no fim das sessões. Evidentemente, ela não sabia - nem era exigível que o soubesse - o que é uma inscrição. E muito menos que ela requer três tempos e não 'dois toques': primeiro tempo, tomar os atos como simbólicos; segundo tempo, instalar a palavra no real do corpo; terceiro tempo, referir essa palavra, no seu valor significante (como representante não representativo desse recorte no corpo, dessa falta), ao discurso.

A atendente pressupunha já cumprida a operação habitualmente a cargo do Outro Primordial (neste caso a mãe). $\mathrm{E}$, a partir desse suposto, deduzia que a operação seguinte deveria ser pedagógica, o que no caso de ser verdadeira sua pressuposição, seria totalmente correto. Ocorre que é assim que chegam as crianças normalmente neuróticas à escola: assujeitadas a uma inscrição simbólicamente eficaz. Mas não é assim que chegam as crianças psicóticas ou autistas à escola ou a uma clínica. Essa primeira tarefa está ainda a ser cumprida. Com a desvantagem de que a criança já padeceu "destempos" nos tempos da tentativa de uma inscrição.

Justamente todo mundo sabe que a oportunidade da mamãe dizer que não a essas pequenas coisas não é indiferente, ela não pode dizer isso em qualquer momento. Não pode introduzir esse "não" em qualquer circunstância ou em qualquer momento porque depende de que série e em que circunstância esse "não" é introduzido, o efeito que isto irá causar. Por isso as mães são extremamente cuidadosas no modo e no momento de introduzir esse 'não'. E de forma alguma porque saibam de teoria psicanalítica, mas porque há um saber inconsciente que as orienta.

\section{O DIALETO ÍNTIMO E O NOME-DO-PAI}

Nós, os terapeutas, não operamos de modo igual ao das mães, mas temos que nos inspirar no discurso materno pelo menos quando registramos que as inscrições primordiais faltam, ou não estão constituídas ou estão falhas. Se não se constitui essa inscrição primordial, esta série de inscrições primordiais, não virá a se constituir na criança um lugar para falar. Essa série de recortes tem um registro tão delicado na instância da letra que cada família tem seu sistema de nomes, um dialeto íntimo. $\mathrm{E}$ até no discurso social, como bem se sabe, existe uma terminologia reservada para essas operações de diferenciação pulsional: o pinto, a perereca, o bumbum, o popô e todas essas simpáticas palavrinhas, esses nomes que são extremamente relevantes e que são o melhor exemplo do que é o Nome do Pai. Vejam só a que fica reduzido o Nome do Pai: bumbum, cocô, popô, pipi, pe- 
rereca, pinto, xexeca, etc.. Não é por acaso que Melanie Klein, que costumava ter uma única entrevista inicial com os pais da criança que analisava e depois nunca mais voltava a vê-los, nessa entrevista inicial perguntava à mãe quais eram os nomes que familiarmente se davam a essas partes do corpo ou aos excrementos, a todos esses pequenos objetos. Isso quer dizer que ela, sem ter uma teoria sobre o Nome do Pai nem sobre o discurso materno, (porque ela certamente tinha uma teoria sobre a relação de objeto mas não sobre o discurso materno nem sobre o Nome do Pai), ela, intuitivamente, por sua sensibilidade clínica, apesar da dificuldade de leitura teórica, registrava que esses pequenos significantes eram extremamente importantes porque eles eram representantes dessas inscrições primordiais.

Dito de outro modo, não há nome próprio sem popô, sem xixi, sem perereca, ou sem pinto, e não porque se tenha um ou uma mas porque designa o que se tem em oposição ao que não se tem, marca a diferença. Se não fosse por esses pequnos 'marcadores' no corpo, o patronímico não quereria dizer nada. Embora o nome que se coloca se coloque arbitrariamente, o próprio nome não é a primeira palavra que uma criança pronuncia. Geralmente é outra palavra: mamãe, dadá, o nome de um irmão ou, às vêzes de seu terapeuta $e$, muito rapidamente, o nome desses pequenos objetos porque eles estão associados de modo muito próximo a esses significantes primordiais do Nome-do-Pai, formam parte dessa constelação denominada Nome-do-Pai, e se chamam assim porque esses significantes suportam a parte mais pesada da função paterna, ou seja, o trabalho de separar pedaços do corpo para lançar ao sujeito a sua simbolização. Separa o cocô do bumbum para lançar o sujeito para simbolizar o cocô.

\section{AS EQUAÇÕES FREUDIANAS E A SUBSTITUIÇÃO DE OBJETO.}

É essa uma das grandes descobertas freudianas que se exprimem nas suas famosas equações: fezes $=$ falo, fezes $=$ presente, fezes $=$ dinheiro, ou a outra série substitutiva, penis $=$ falo $=$ filho, onde o último significante tem uma potencialidade substitutiva muito mais larga do que o primeiro. Opera-se uma amplificação semântica ao mesmo tempo em que se produz um certo apagamento do aspecto representacional do objeto substituído, ou seja, vai-se abrindo a possibilidade simbólica. A extensão dos efeitos de significância desse objeto evidentemente muda do cocô ao dinheiro.Assim também acontece do pênis ao falo, e da falta de pênis ou da pereca ao filho. 'Perereca' parece ser uma boa escolha como significante, porque no fim das contas ela passa o tempo todo pulando de uma posição a outra, representando nisso a posição pulsional feminina: fazer mil acrobacias para disfarçar a castração que 
ela supôe real. Ou, na frase de J.Lacan (1984), "fazer tudo e mais um pouco com nada".

Essa equações não operam se não se articula essa inscrição primordial na direção desse lançamento simbólico. Dito de outro modo, para que o objeto não fique sendo ele mesmo e somente ele mesmo, é necessário transformar cocô em dádiva. $\mathrm{E}$ isso as mães sabem fazer muito bem... Por isso é que não vacilam, e embora saibam que seu bebê é incapaz de compreendê-lo tudo, o supõem falante.Se ele diz:" Aaaaaah !", a mãe diz: "Está me chamando!" Onde ela escutou que a estava chamando ? Se a mãe diz que ele emitiu um som em Mi Bemol, estamos diante de um grave problema, porque é necessário que ela tome essa voz como do âmbito da palavra. Ou seja, colocar o seu filho na posição de escuta quando na verdade ele não sabe escutar mas apenas ouvir, e escutar seu filho quando na verdade ele não produz realmente nada que possa ser escutado, apenas ouvido. Essa sutil mas decisiva diferença de função entre perceber a voz - ouvir, e diferenciar a palavra - escutar.

\section{DIFERENÇAS DE ESTRUTURA ENTRE PSICOSE E AUTISMO}

Se a criança não for situada deste modo em relação aos objetos, não haverá diversidade de objetos, quer dizer, seu interesse ou sua relação ficará toda capturada nesses pequenos representantes do real do objeto. O que a deixará girando ao redor do cocô, do xixi, de seus membros, de sua pele, de seu toque, de seu olhar, do impacto da luz em seus olhos ou em sons reiterativos, ou seu labirinto que o informa de seus movimentos, etc. É evidente que estamos falando do autismo, esta posição onde não há um sujeito porque não foi produzida essa separação destes fragmentos do corpo. Porque é assim que a criança vivencia esses cortes; quando lhe tiram o peito da boca é como se lhe arrancassem a boca, e quando faz cocô é como se separasse um pedaço de seu corpo. É por isso que as crianças em geral não aceitam pacíficamente o desmame, a hora de fechar os olhos (leiase: separa-se do olhar do Outro) para dormir, ou tomam os devidos cuidados para começar seus experimentos esfincterianos, pedem penico, ou seja, tentam não perder esses objetos.

As crianças autistas ficam tomadas no real do objeto e é por isso que se apegam de um modo absoluto e persistente a quase qualquer coisa que as impacte do ponto de vista físico e que chame sua atenção, ou seja, que gere uma descontinuidade física na superfície indiferenciada de seu corpo. É por isso que são capazes de passar um ano inteiro esfregando o dedo sobre uma pequena ruga de uma folha de papel, sobre a aspereza de uma superfície ou se balançando na frente de uma luz provocando, assim, uma variação luminosa. Não podem chegar mais longe do que isso porque não há inscrição desses objetos, eles não têm nome, não foram separados de seu corpo e, por isso mesmo, não há corpo, pelo menos não há no mesmo sentido que nós o concebemos. O objeto não é simbolizável, e por isso não há substituição.

É claro que os psicóticos recebem uma certa marca, uma certa inscrição, mas o problema é que esta inscrição não pode chegar muito longe pois a receberam de um modo tal, esta marca foi feita com tal material significante que o elástico simbólico não pode se esticar ou se estica muito pouco. A série que se pode estender a partir do cocô não chega nunca no dinheiro - tomando a equação freudiana - ou o elástico 
simbólico que eu posso estender a partir da sua amarração na castração não chega nunca no filho de um homem, ou seja, a equação pênis-falo- filho não se constitui. Às vezes o penis mal chega no falo, ou o cocô mal chega no presente. As equações que Freud elaborou assinalam pontos de estação relevantes numa caminhada significante que é muito mais extensa do que esse trecho de três termos por ele assinalados. $\mathrm{Na}$ verdade a série significante que vai desse pequeno objeto a ser recortado $\mathrm{e}$ inscrito, até o termo mais algébrico que represente esse objeto, essa série é infinita. $O$ que Freud sublinha é que vale a pena marcar algumas estações delicadas dela, ou seja, momentos traumáticos da elaboração dessa passagem.

Levando em conta que os psicóticos recebem esta inscrição de tal maneira que o elástico não se estica muito, se o leitor teve a paciência de nos acompanhar até aquí, seguramente estará se perguntando, a essas alturas dos desdobramentos de nosso texto, o que tem haver o sincrônico e o diacrônico com tudo isso. A razão fundamental de que chamássemos a atenção para o sincrônico e o diacrônico reside em que no modo como venham se produzir essas inscrições primordiais já estará contido, até um certo ponto, o nível de possibilidade ou impossibilidade da extensão semântica, o nível do esticamento simbólico possível. Agora bem, esse modo, ou seja, as condiçôes introduzidas para que a inscrição possa operar como tal, depende de que os pais desta criança reconheçam como legítimo o fato dela estar marcada desse modo. Ou seja, que o fato de a criança ter incorporado essa inscrição tem que funcionar de um modo tal que ela se torne legítima agente do exercício das conseqüências dessa inscrição. Essas condições são de uma natureza, extensão e complexidade tais que podem colocar a criança numa dificuldade radical de poder fazer exercício de suas consequiências, apesar de ter recebido tal inscrição. Dito de modo mais simples, não basta ensinar a manejar os talheres para que a criança se sinta em condições de comer sozinha. O que vai determinar se a criança vai se sentir ou não em condições de comer sozinha é o quanto de reconhecimento ou o quanto de narcisismo ela pode recuperar nesse ato, no reconhecimento de seus pais, o quanto se reconhece como legítimo agente do exercício da técnica dos talheres. É assim que há muitas crianças que dominam perfeitamente a técnica de manejo dos talheres mas não comem sozinhas. E para falarmos do que ilustra isto de um modo escancarado, temos os pacientes adolescentes com quadros psicóticos anoréxicos, onde não há dúvida de que o exercício técnico do garfo e da faca não falta, mas a mãe tem que dar-lhe de comer na boca porque senão o paciente não come, $e$ às vezes nem com a intervenção da mãe.

Com isso, pode-se ver que a questão da inscrição é bastante mais complexa do que essa formulação que propusemos no início de nosso texto, quando, a modo de introdução, marcamos o ponto de partida da inscrição quando uma mãe diz não. A operação é bastante mais complexa e tem, evidentemente, consequências mais duradouras e mais complicadas do que simplesmente oportunizar sua contrapartida mais freqüentemente manifesta sob a forma aparente de uma simples rebeldia.

A estas alturas já é possível perceber que nessa diacronia de colocar uma palavra atrás da outra, de colocar o significante presente depois do significante cocô, e o significante dinheiro depois do significante falo e assim sucessivamente, que nessa diacronia do pro- 
gressivo distanciamento dessa versão original e primordial do objeto, há, porém, uma sincronia que faz seu efeito. Esta sincronia que se adverte quando registramos que já nos primeiros movimentos dessa inscrição se aninham as condições ou pré-condições da extensão semântica, do nível de esticamento simbólico que, apartir desse pequeno objeto recortado de uma tal maneira, poderá vir a se produzir. Não é que nessa inscrição primordial já esteja contido que o filho será engenheiro químico, - isso seria da ordem da predestinação -, nem sequer se ele vai ter condições ou não de chegar a ser engenheiro, se ele vai ser aprovado na escola secundária, nem tampouco se ele vai aprender a ler.

Nessa inscrição primordial nada de sua aprendizagem está pré determinada. A única coisa que está estabelecida é algo assim como o vasilhame, pior ainda, uma forma, uma sombra ainda por cima recalcada. Uma sombra de uma forma do vasilhame onde ele vai encaixando os objetos que a experiência da vida vai lhe oferecer. Os pais e os mestres, sabendo disso, vão oferecendo às crianças experiências de vida porque sabem muito bem que com as inscrições primordiais, uma vez chegando as condições de simbolização, a aprendizagem não está garantida. Assim é que os professores se preocupam também em elaborar uma boa didática, ou seja, uma boa técnica de apresentação dos objetos que permita perceber as suas diferenças, seus valores, suas qualidades, suas relações, suas analogias, suas características, etc.. É claro que em cada objeto que a criança for indagar e investigar vai estar presente essa modalização que aquela inscrição primária estruturou. Ou seja, que se para uma criança foram colocadas, nessa inscrição primária, pré-condições e exigências demasiadamente complexas para reconhecer sua legitimidade, ou seja, se lhe colocaram obstáculos, em cada confronto com um novo objeto esses obstáculos serão reeditados. Não há outra possibilidade.

\section{PARTICULARIDADES DAS APRENDIZAGENS NAS PSICOSES}

É por isso que os psicóticos têm dificuldade para aprender, e não porque não são inteligentes. É sabido que alguns psicóticos são mais inteligentes que muitos neuróticos normais, o que rápidamente vem demonstrar que a inteligência não é equivalente à simbolização, por mais que a Piaget pareça que $\operatorname{sim}^{11}$. Não é porque certamente há delírios paranóicos que são de um nível de abstração maravilhoso, abstração reflexionante da melhor. Há delírios paranóicos que são do melhor nível de abstração reflexionante mas eles fracassam na simbolização porque precipitam no real. As alucinações também podem ser governadas por uma lógica reflexionante, é assim que os dispositivos mecânicos e os aparelhos imaginados por esquizofrênicos reproduzem de um modo surpreendente relações lógicas do aparelho mental com se fossem uma colocação em máquina do modo como pensamos. Por sinal, em última instância, essa máquinas não servem para nada ,ou seja, são totalmente equivalentes ao real de nosso pensamento que tampouco serve para coisa alguma. Assim devemos considerar as coisas se levarmos em conta que o pensamento é o exercício que fazemos entre o nascimento e a morte na esperança de que sirva para produzir uma separação infinita entre uma ponta e a outra. Isso sempre fracassa; assim, daqui a cem anos, quem vai saber o que que nós pensamos? Em última instância, para 
cada um, sem tomarmos a entidade coletiva do sujeito, para cada um, o pensamento é exatamente igual a essas máquinas esquizofrênicas, não serve em última instância para nada.

Isso demonstra a estranha virtude que têm os psicóticos de nos revelar as coisas como elas são, enquanto nós, neuróticos, somos mestres em disfarçálas. É por isso que o psicótico pode andar nu pela rua e o neurótico, a não ser que seja uma candidata a atriz no festival de Cannes, não. Além disso só o faz se sua "roupagem" for das boas, ou seja, se tem o que oferecer ao olhar do outro. Então, se na relação com cada objeto vai se reeditar inevitavelmente a modalização da relação de objeto que se inscreveu de modo primordial, isso quer dizer que nessa diacronia da apresentação sucessiva dos objetos e dos significantes há algo de sincrônico porque a mesma estrutura vai se repetir. É o que Freud diz quando analisa a curiosidade sexual da criança pela cena primária, essa curiosidade que se instala tão precocemente e que faz com que uma criança de dois anos todas as noites levante de sua cama e vá até a cama de papai e mamãe querendo entrar no meio, não porque queira separá-los mas porque quer averiguar o que há no meio, o que acontece ali; essa curiosidade que faz com que criança coloque o dedo em todos os buracos e queira espreitar por'todas as fechaduras ou por todas as frestas. Essa espreita é irresistível para elas porque do outro lado, seguramente, deve estar o segredo do que a mãe lhe diz para não olhar. Então ela vai olhar para ver se vê, e senão for nessa fresta será na próxima e assim sucessivamente, e também, se não puder ver, talvez consiga tocar alguma pista relativa ao segredo, que, em última instância, - nós o sabemos - é a cena primária.

Freud (1973) diz que é essa curio- sidade que vai inspirar toda inquietação cognoscente, ou seja, toda curiosidade de conhecer. Seria ali, então, que se organiza qualquer coisa que pudesse ser chamada de 'pulsão epistemofílica', talvez como uma forma na qual a pulsão generaliza a falta de seu objeto. Portanto, se há uma falha na inscrição primordial e se ela se realiza sob a forma de forcluir, ou seja obturar, qualquer curiosidade sobre as transformações simbólicas desse objeto, se não houver transformações simbólicas, a criança não tem o que perguntar, não tem para onde dirigir sua interrogação porque o objeto já está aí, cocô é cocô e acabou a história. Não há espaço para indagar que posição esse objeto tem na cadeia simbólica do Outro. É por isso que não há conhecimento propriamente dito se o enunciado que o sustenta não tem uma posição simbólica. É um conhecimento que poderá estar ordenado do ponto de vista da lógica pura mas oferece a cada passo o equívoco de o outro supor um simbólico, quando, em verdade, está se referindo a um real. É por isso que um tal conhecimento, assim limitada a extensão semântica de seu enunciado, não sustenta nenhuma possibilidade de produzir um exercício de pesquisa. Qualquer indagação sobre as relações do significante com o real é desnecessária porque o real já está alí. Pelo contrário, se trata de defender o sistema de pensamento das invasões devastadoras do real. Por isso há psicóticos que não cessam de produzir autônimos, como também há os que instrumentalizam sua capacidade de raciocínio lógico ao serviço de construir um sistema fechado de pensamento, que gira ao redor de alguma metáfora, não paterna, mas de uma certa extensão simbólica. Trata-se, em todos os casos, de estabelecer um certo status quo.com o real. Esse tipo de solução funciona como uma lagartixa devorando seu pró- 
prio rabo. Portanto teríamos que nos perguntar se isso mereceria o nome de conhecimento, embora, certamente, seja um efeito dessa função imaginária do Eu que chamamos 'cognitiva'.

Perceba-se que não estamos dizendo que não há conhecimento no psicótico, mas indagando das dificuldades e especificidades de sua constituição. Por sinal, também estamos assinalando seus limites.

É aí que surge uma primeira razão para que existam escolas para psicóticos porque não é o mesmo que ensinar uma criança que estruturalmente já tem constituída a sua curiosidade. É claro que aqui surge a pergunta: é possível ensinar alguém que não tenha constituída essa curiosidade primordial? Prima facie, não. Então, uma segunda pergunta: é possível constituir formas de promover curiosidades parciais, fragmentárias, que permitam a essa criança assim constituída como sujeito, falida na sua constituição simbólica, que ela possa aprender algumas coisas se bem que esses conhecimentos não possam ser generalizados e tenham um uso de uma extensão mais curta? Sim, isso sim. Mas é evidente que um professor que não esteja em condições especializadas de trabalhar de um modo um pouco diferente, no sentido de que leve em conta que essa criança não está nessa posição de curiosidade como todas as outras, vai fracassar.

Então, temos que é difícil para uma criança psicótica aprender em uma escola comum. O que imediatamente traz à tona a questão de se a criança psicótica deve ser segregada da comunidade escolar e ir a uma escola onde se reúnam somente todos os psicóticos. A resposta é: às vezes sim, às vezes não. Depende de que grau de extensão tenham as metáforas não paternas que cada criança psicótica em particular poderia vir a constituir, para encontrar pontos de referência que mobilizem seu desejo de aprender, sua curiosidade. $\mathrm{O}$ que quer dizer metáfora não paterna? Quer dizer descobrir uma série significante com suficiente peso de significancia na vida do sujeito psicótico para servir de referencia para um conjunto mais ou menos extenso de significações possíveis, de tal modo que, atuando como substituição parcial de Nome-doPai forcluido, permita ao sujeito em questão um certo nível de circulação social e, também, de resolução de sua angústia siderativa.

Agora, evidentemente, a substituição não vai funcionar de modo tão extenso, flexível, estável ou persistente como aquelas originárias. Fabrica-se uma referência que lhe serve para interpretar uma série de situações e circunstâncias, mas que além desse círculo de situações e circunstâncias não the diz nada. Então temos que fabricar outras e outras e outras..., ou seja, uma construção delirante, outra construção delirante e outra... Das quais ficamos situados como garantias, como fiadores, na transferência.

A justificação ética de apelarmos a esse recurso, a essa montagem, reside em que, em última instância, até mesmo as construções simbólicas neuróticas (chamadas de normais), são delirantes.

Acontece que os delírios neuróticos têm duas características que lhes permitem movimentar-se como se fossem normais na sociedade. A primeira característica é que o delírio neurótico coincide com o sintoma social prevalecente. Se os neuróticos vivessem em uma sociedade psicótica, seriam seres estranhos. Por isso nos hospitais psiquiátricos, quando trabalhamos ali, os loucos formam uma comunidade e nos olham como bichos raros porque nós pensamos num código diferente do deles. A segunda razão que permite aos neuróticos circularem mais ou menos 
normalmente na sociedade é que seu delírio é coletivo, eles participam de delírios coletivos. Eles tem esse 'cuidado', a religião que praticam é coletiva. Se é uma religião compartilhada somente por dois já fica suspeito. "Eu e minha mulher inventamos uma religião", ai fica suspeito.

\section{A INCLUSÃO DE CRIANCCAS AUTISTAS E PSICÓTICAS NA ESCOLA COMUM}

Bem, diziamos, acerca da inclusão da criança psicótica na escola comum, que isso era viável, às vezes sim, às vezes não, dependendo da extensão, da flexibilidade, da proliferação desses arremedos de função paterna que ela consiga fabricar, geralmente com a ajuda de outros. É evidente então que numa escola para psicóticos ou numa escola onde haja psicóticos, - porque não tem por que ser somente para eles, é necessário que haja alguém que seja capaz de interpretar essa fragmentação de sua simbolização e ajudá-lo a constituir novas metáforas ali onde as suas próprias não alcançam. Por outro lado. devemos considerar que há formas da psicose tão incômodas para os neuróticos, para as crianças neuróticas, que estas mal suportam o convívio com essas formas da psicose. E geralmente as crianças neuróticas na escola estão num momento de sua vida que, embora dentro normal, do comum e corrente, atravessam situações delicadas, pelo simples fato de estarem numa idade em que as elaborações primordiais ainda se encontram em curso, e a possibilidade de se confrontarem com formas extremamente estranhas e distoantes da própria imagem - situada num semeIhante - coloca em questão os pontos de identificação imaginária, de especularização com o outro. Isso porque a criança até a puberdade está submetida aos riscos da ruptura do espelho no qual se reconhece. Risco que se nota muito bem quando uma criança muito nova perde seus pais. Temos como recente e bem próximo exemplo os sequestros de crianças filhos de militantes revolucionários na Argentina durante a ditadura militar, e que agora, na adolescência, estão chegando às consultas porque o apagamento ou a quebra do espelho no qual estas crianças se reconheciam acarretou para elas consequências psíquicas graves. Nessa mesma direção, é bem conhecido por nós que quando uma criança, por razões familiares, se encontra obrigada a conviver com um parente psicótico, isso tem consequências para ela. Isto não quer dizer que ela se transforme em psicótica, mas certamente terá bons padecimentos neuróticos. Costumamos receber em consultas de adultos os efeitos tardios dessas vicissitudes infantis.

Então não parece razoável pensar que não haverá alguma consequência para crianças neuróticas que não têm outra imagem de reconhecimento que aquela do semelhante neurótico se elas forem submetidas a um convívio cotidiano com formas extremamente agressivas da psicose. Por mais que sejamos partidários da não segregação dos psicóticos, não podemos, geralmente, responder a esse questionamento tão comum dos pais, quando uma criança que tem problemas graves é incluida junto com seu filho 'normal' e o pai expressa a preocupação de se isso não fará mal a seu filho.

Devemos confessar que nós somos partidários da integração, sem dúvida, mas que quando surge, na turma que nossos próprios filhos freqüentam, uma criança com problemas graves, imediatamente nos perguntamos se 
isso não terá consequências para nossos filhos. Geralmente tendemos a subestimar os efeitos, a disfarçá-los ou até a responder para nós mesmos que a consistência fálica de nossos filhos será suficiente para resistir ao choque. Como sempre, quando ficamos acuados, a última solução é narcísica. Porque cabe nos perguntarmos se não será essa uma secreta tentativa de que nossos filhos sejam tão terapeutas quanto nós?. E, como nossos filhos costumam entender muito bem disso, acabam sendo terapeutas dessas crianças. Nas supervisões e análises de profissionais que se dedicam aos problemas graves da infância encontramos essas manifestações com farta frequência e, no que me diz respeito, confesso que tudo o que acabo de manifestar num tom geral eu poderia dizê-lo em nome próprio também. Porém, para quem procede de modo psicanalítico, seja analista ou não, esta observação serve para nos prevenirmos de não nos centrarmos em qualquer referência narcísica para a tomada de decisões clínicas a este respeito. A pergunta que precisamos nos formular, para orientar nossas prescrições neste campo, é a seguinte: em que posição ficará a criança psicótica ou autista perante o discurso, se ela for incluída numa escola com tal ou qual carateristica?

Aqui surge uma necessidade de decidirmos caso a caso quem é que pode participar da vida escolar comum e quem é que requer uma escola para psicóticos. E os que requerem uma escola para psicóticos, evidentemente, são uma minoria, mas isso não quer dizer que não existam em número suficiente para justificar uma atividade específica que os auxilie. Até aquí, a primeira das razões de por que devem existir escolas para psicóticos parece-nos mais ou menos demonstrada.

\section{DE COMO UM FALSO IGUALITARISMO PODE ACABAR EM SEGREGAÇÃO}

Preferimos falar agora da terceira razão antes da segunda, para faciliatar nossa demonstração. Essa terceira razão, que qualificamos como de ordem social, é relativamente simples. Lembremos, para começar, que o hospital psiquiátrico é a estação final do trem da psicoses. Nós, terapeutas, tentamos sempre que o psicótico desembarque antes de chegar à parada final, mas que ele consiga ou não fazê-lo depende de muitas circunstâncias (o unwelt, na denominação de S. Freud), mas também, e fundamentalmente, do modo como foram realizadas aquelas inscrições originárias, do modo como elas vieram ou não a se confirmar na adolescência. E, do ângulo terapêutico, depende da possibilidade de nós encontrarmos alguma maneira de mudar algo na posição fantasmática que esteve reservada a esse filho no discurso parental, durante o transcurso de sua infância. Se conseguirmos mudar a posição fantasmática que esse filho ocupa no discurso parental, teremos uma 
grande chance de que ele desembarque bem antes dessa parada final, seja porque a sua estrutura se transformou e ele deixou, então, de ser psicótico - o que em alguns casos, antes da puberdade, é possível -, seja porque sua psicose se articulou de um modo tal que não o impede de funcionar socialmente. Essas opções - que não são fáceis de se produzirem - poderão permitir-lhe descer do trem que conduz os psicóticos ao exílio manicomial antes de chegar ao fim da linha.

Quando uma criança é pequena e é psicótica, as insuficiências simbólicas ou as restrições de simbolização (originadas na forclusão, parcial ou total da Função Paterna) que caracterizam a sua psicose, confundem-se ou tendem a se confundir com as insuficiências das aprendizagens, sobre tudo nas crianças pequenas. Que uma criança não saiba fazer isto ou aquilo ou que não consiga articular sua relação com o outro, isto tende a ser indistintamente explicado por ela ser ainda pequena e não pela sua psicose. Assim, é comum que algo que não é próprio da condição de infans, de não falante - por exemplo, uma criança de quatro anos que não fala - seja tomado como equivalente à condição de infans de uma criança de um ano e meio que ainda não fala. Como, além do mais, geralmente a criança psicótica de três ou quatro anos faz cocô nas calças e usa fraldas, ou não pasou do alimento líquido ao sólido, ou não consegue se distanciar da mãe, etc., há uma tendência em se estabelecer uma série de equivalências entre essa criança e o infans. Em outros termos, suas manifestações psicóticas são confundidas com expressões normais de um bebê que, na realidade, já não mais existe.

Paradoxalmente, isto permite que muitas crianças psicóticas e autistas frequentem as escolas comuns enturmadas em grupos de crianças menores do que elas, em função dessa suposta equivalência entre crianças de quatro anos com características autísticas e portanto com perturbações no seu desenvolvimento, e crianças, por exemplo, de dois anos com caraterísticas neuróticas normais. Os indubitáveis beneficios desse convívio podem se anular na medida em que tal prática fique ao serviço de mascarar a patología em curso e, com isso, a criança fique subtraida à intervenção clínica imprescindível, prolongando desse modo o retardo em sua estruturação psíquica, cultivando um adiamento que pode acabar no cancelamento definitivo da sua possibilidade de compartilhar o discurso social.

Os beneficios desse convívio se derivam do fato de que as crianças neuróticas oferecem chances às psicóticas, às vezes pela via do mimetismo, às vezes pela via da identificação, de tomar alguns traços circulantes no discurso grupal para articular formas de simbolização, metáforas não paternas, que lhes permitam participar da vida social de um modo um pouco mais plástico. Isto de fato acontece, ainda que não sempre, pois depende do grau de isolamento. Isto quer dizer que não se pode generalizar, como uma prescrição universal, para que todas as crianças autistas ou psicóticas frequentem o jardim comum. Certamente há crianças autistas que podem ficar completamente perdidas e brutalmente isoladas, na ausência de alguém que possa se dedicar exclusivamente a elas. Mas há uma série de crianças psicóticas e alguns pós autistas que, graças a intervenções clínicas precoces, conquistam uma possibilidade de aproveitar de uma certa convivência, de uma certa identificação que, ainda que contingente, thes permite circular socialmente. As marcas residuais dessa experiência de confronto com um discurso que não faz deles objetos de 
exclusão (no autismo), ou pertencimento fálico do Outro Primordial (nas psicoses), tendem a constituir uma espécie de reservatório de significantes que funcionam de modo diferente daqueles até ali inscritos, o que permite sua implementação para o processo de recuperação, e que funcionam como verdadeiros pontais na direção da cura. Embora as significaçôes possam continuar determinadas pela forclusão, esse contato com um mundo significante que funciona na referência a um pai (seja lá qual for), parece funcionar, nas crianças psicóticas, como uma janela de luz aberta nessas trevas exteriores em que foi lançado aquele significante primordial que fora rechaçado 12 .

Até aí, então, socialmente não haveria razão para que houvesse escolas para psicóticos, e sim exatamente o contrário. Porém, quando chegamos à adolescência a coisa se complica. Tomamos a adolescência porque é o outro extremo da situação. A coisa se complica precisamente porque se o psicótico que foi psicótico sempre, desde criança, ou o autista que foi autista desde criança e que agora é um pós autista ou um psicótico, se eles vão produzir seus atos como infans ainda, seus atos não serão tomados como os de uma criança pelo discurso social. Dito de outro modo, se uma criança de três anos abaixa as calças no pátio, é uma brincadeira infantil, mas se um psicótico de dezoito anos faz a mesma coisa, do ponto de vista do discurso social isto já não é mais uma brincadeira. Ainda que nós, terapeutas, sejamos capazes de perceber quanto de infantil ainda resta nesse ato, nem mesmo as terapeutas mais heróicas suportam a perseguição de seu excitado paciente de dezoito anos pelo pátio da escolas. Estamos nos referindo a uma situação cômica que evocamos facilmente porque se trata, no caso, de um acontecimento recente numa instituição na qual trabalhamos: um adolescente psicótico de dezoito anos com uma posição completamente infantil, completamente apaixonado por uma terapeuta ocupacional, perseguiua, sem roupa, pelo corredor. Então, ela perguntou, na supervisão de equipe: "Até onde devemos suportar?"

Bom, eis aqui o problema do limite que, por sinal, não é meramente o problema de por limites, de dizer não, mas de resolver em que situação esse limite deve ser colocado para que cumpra alguma função de transformação de uma coisa em outra coisa. Se não for assim, não é no sentido próprio um limite. D.W.Winnicott dizia que o limite é o que transforma uma coisa em outra coisa, senão não constitui limite mas somente uma imposição. Nesse ponto ele tinha toda razão. Ou seja, não é simplesmente dizer que não, porque se dissermos simplesmente não, a coisa (no sentido propriamente freudiano) continua a mesma, e, por tanto, teremos que continuar a dizer que não o tempo todo, ou ter um cassetete na mão.

As questões se complicam na adolescência por esse motivo: porque já não é mais possivel tomar esses atos como brincadeira, ainda que quem os execute os conserve no campo de uma relação infantil do significante com o real ${ }^{13}$. Estamos falando até agora daqueles que foram reconhecidos como psicóticos desde muito cedo, que atravessaram sua infância como psicóticos, muitos deles encefalopatas, com problemas de lesões cerebrais, etc. Ainda quando se trata de sujeitos que estão nesta situação, a partir da conclusão da puberdade e início da adolescência, se suas formas psicóticas forem muito discrepantes das formas que o discurso social suporta, ou seja, se tendem a produzir situações que são tomadas como atos reais pelo discurso social, as soluções terapêuticas que se abrem são 
evidentemente as de internação, ou em casa ou no hospital psiquiátrico. Porque o jovem psicótico, com toda a sua aparência civilizada, rodeado dos mais modernos conceitos de integração e não discriminação, tanto da parte de seus pais quanto dos terapeutas envolvidos, andando pela rua vai levantar o dedo na cara do boxeador que mora na esquina e levar um soco que fará com que acabe no hospital, ou vai querer parar o trânsito, brincando de policial, e será atropelado por um carro, ou vai andar nu e ser preso por atentado contra a moral. Então, para onde mandá-lo, qual é seu lugar? Se for parar no hospital psiquiátrico, estaria indo cedo demais porque na adolescência existem chances ainda, em função do carácter re-fundante dos traumas próprios da adolescência $^{13}$, de virem a se produzir novas inscrições que modifiquem até certo ponto o modo do funcionamento psicótico.

\section{A IMPORTÂNCIA DO SIGNIFICANTE ESCOLA}

É aí que a figura da escola kem a calhar porque a escola não é socialmente um depósito como o hospital psiquiátrico, a escola é um lugar para entrar e sair, é um lugar de trânsito. Além do mais, do ponto de vista da representação social, a escola é uma instituição normal da sociedade, por onde circula, em certa proporção, a normalidade social. Portanto alguém que frequenta a escola se sente geralmente mais reconhecido socialmente do que aquele que não frequenta. É assim que muitos de nossos psicóticos púberes ou adolescentes reclamam que querem ir à escola como seus irmãos precisamente porque isso funcionaria para eles como um signo de reconhecimento de serem capazes de circular, numa certa pro- porção, pela norma social. E efetivamente isso acaba tendo um efeito terapêutico porque, do lado do discurso social, cura esse discurso de seu horror à psicose, ou cura, numa certa proporção, às vezes mínima, às vezes maior, às vezes num efeito apenas circunscrito à comunidade escolar ou ao bairro onde a escola está, cura, dizíamos, um certo número de preconceitos. Nesse sentido podemos lembar algumas experiências das equipes de escolas para psicóticos ou autistas, ou mesmo daquelas dedicadas aos deficientes mentais, quando saem a passear pelas vizinhanças com seus paciente-alunos. Registra-se quase invariavelmente um acolhimento progressivo e uma crescente disponibilidade dos vizinhos para "ajudar" na trabalhosa tarefa de abrir brechas de comunicação dessas crianças ou adolescentes com o âmbito social. A circulação por pequenas lojas e "botecos", e até mesmo por prédios e casas de vizinhos vai se tornando lentamente viável $^{14}$. A conquista de uma certa popularidade aparece em nome do fato de que "eles são os da escola aqui do lado", e não há dúvida de que as reações seriam muito diferentes se se trata de "os do manicômio"; o significante, como sempre, pode se decisivo. Porque escola é coisa de criança, no final das contas se esses meninos e meninas têm problemas mas estão na escola, seus atos viram artes. Se gritam demais, se se aproximam demais, pulam demais, comem demais, põem a mão onde não devem, são simplesmente meninos e meninas, seguramente o são porque vão na escola. Quem sai do manicômio não tem esse benefício na leitura social. Essa razão social muito simples nos leva a pensar que é interessante que existam escolas para psicóticos.

Agora vejamos a segunda razão. A segunda razão é do seguinte teor, é a razão fundamental pela qual o trata- 
mento de um psicótico tem que ser necessariamente interdisciplinar e não multidisciplinar. A cura da psicose não pode passar exclusivamente nem pela psiquiatria, nem exclusivamente pela psicanálise, nem pela terapia ocupacional, fonoaudiologia, nem exclusivamente por lugar nenhum, nunca. Isso não quer dizer que um psicótico tenha que ter quinze terapeutas.

\section{A FUNÇÃO COGNITIVA NÃO É AUTÔNOMA NEM AUTOMÁTICA}

Diziamos que a segunda razão para a existência de escolas terapêuticas para psicóticos reside num princípio da cura. Vamos dar um exemplo para ficar mais claro. Uma vez um colega analista, que não trabalha de um modo interdisciplinar e que trabalha com crianças, me contou por generosidade, para fazer um intercâmbio entre nós, um caso muito interessante de um menino que começou um tratamento com ele quando tinha quatro anos. Apresentava-se na época com uma psicose e agora, nesse momento do relato, o menino já tinha oito anos e tinha deixado de ser psicótico. Essa última afirmação não é cem por cento segura, já que teríamos que esperar até adolescência para nos certificarmos disto, mas poderíamos dizer que era uma afirmação com boas chances de ser verdadeira. Pelo menos, certamente, o menino - ou melhor, o sujeito - aos oito anos não era o mesmo que aos quatro. Evidentemente, dos quatro aos oito ele atravessou o momento de iniciação escolar com a idade em que isso acontece. E efetivamente ele havia começado a ir à pré-escola, não tinha ido antes a nenhum jardim de infância. Então, como era de se esperar, quando começou a frequentar a préescola, apresentou muitas dificuldades e desajustes, e esse analista optou por indicar aos pais que não era momento propício para incorporá-lo na escolaridade. $E$ isto permaneceu assim até o momento daquele relato, aos oito anos.

Ao terminar seu relato de um caso psicanaliticamente tratado- sem dúvida de modo brilhante, com interpretações invejáveis, que nós teriamos gostado muito de ter feito - eu lhe perguntei: "e ele vai à escola?" - uma pergunta ingênua, inocente, sem nenhuma intenção interpretativa. Pensei que ele ia responder "sim, mas tem dificuldades...". Mas não. O analista, como resposta, contou isso: que ele tinha optado por contraindicar a frequência à escola. Então eu indaguei: " bom, mas e a aprendizagem dele?". Ele concluiu: "disso eu não me ocupo". Eu compreendo isso, porque evidentemente não pode se ocupar de tudo, e além do mais, na posição transferencial de analista, ele não pode produzir atos pedagógicos. Então ainda insisto:" Mas eu não pergunto se você se ocupa, eu pergunto se propõe que alguém se ocupe". E vem seu revide: "Eu considero que a restituição da potencialidade simbólica, ou seja, a restituição da posição de inscrição sucessiva que lhe permita simbolizar é o fundamental, o resto vai crescendo. Minha resposta: "não, não vai crescer". Não é uma derivação automática, porque o que durante oito anos ficou como saldo negativo na apropriação lógica do objeto, este deficit lógico que se acumulou durante oito anos não vai se saldar automaticamente como num passe de mágica só pelo fato de ele agora dispor de uma posição que lhe permita simbolizar. Ele vai ter que viver as experiências e passar pela experimentação que não atravessou, justamente porque não estava em condições de fazê-lo. $\mathrm{E}$ se alguém não se ocupa de abrir-lhe caminho nessa direção, ele sozinho não vai poder. E, o que é ainda pior, vai 
tropeçar com uma defasagem com relação às outras crianças de oito anos. Uma defasagem que pode se tranformar numa ferida narcísica, ou numa perda melancolizante. Porque ele vai tropeçar com o fato de que o objeto do conhecimento, que seus pares construíram nesses anos todos em que ele esteve dedicado a refazer sua posição subjetiva, funciona para ele como um objeto definitivamente perdido, já que essa desvantagem em relação aos outros se lhe apresenta como se fosse irredutivel. Ou seja, um objeto perdido que doravante vai acompanhá-lo sempre. A partir disto, ele terá boas chances de se transformar num melancólico da aprendizagem, com as subseqüentes relações agressivas com os representantes imaginários de sua perda, sejam eles objetos de conhecimento ou pessoas. Bem diferente seria sua situação se alguém tivesse tido a paciência e dedicação de lhe ensinar na língua "estrangeira" que, por ser psicótico, ele falava. Nesse caso, os traços residuais daquele objeto fragmentar de sua psicose, cultivados na dimensão significante pelos mestres especializados, aquela lógica, embora exercitada numa inevitável direção delirante ou autônima ${ }^{15}$, poderiam ser capturados no après coup dessa função simbólica nele recentemente inaugurada. A sutura de sua desvantagem em relação a seus pares seria, então, seguramente mais provável. Esta é uma segunda e, em nosso parecer, decisiva razão pela qual devem existir escolas para psicóticos.

\section{UMA CONTROVERSIA INEVITÁVEL}

Três razões que se conjugam trabalhosamente, por um lado, com os perigos da discriminação e da marginalização, e, por outro lado, com uma dura resistência familiar e social. Uma dura resistência freqüentemente formulada ora num falso democratismo que confunde uma questão de sintoma com uma questão de direito, ora num igualitarismo puramente imaginário, muito mais destinado a satisfazer o narcisismo dos pais ou as aparências políticas do que as verdadeiras necessidades clínicas das crianças que padecem destas dificuldades.

\section{REFERÊNCIAS BIBLIOGRÁFICAS}

FREUD, Sigmund (1973). Un recuerdo infantil de Leonardo da Vinci. In: Obras completas, v.2, Madrid, Biblioteca Nueva [1910].

LACAN, Jacques (1981). Las Psicosis, Seminário III. Buenos Aires, Paidós.

LACAN, Jacques (1984). Aún, Seminário XX. Buenos Aires, Paidós.

PIAGET, Jean (1969). Biologia y' Conocimento. Madrid, Siglo XXI. 


\section{NOTAS}

(Este texto está inspirado num seminário proferido no Instituto de Psicología da Universidade de São Paulo, em 1996.)

1 KUPFER, M. Cristina, A presença da Psicanálise nos dispositivos institucionais de tratamento da psicose. Estilos da Clínica. São Paulo, Instituto de Psicología da USP, ano 1, n. 1, 1996, p. 24-30.

2 Ver em DOSSE, François, História do Estruturalismo, São Paulo, Ensaio UNICAMP, 1994, vol.2, ps. 98 e 336, comentário sobre a posição clássica de J. Piaget no estruturalismo e sua proximidade com as posiçôes de Lucien Goldmann.

3 Veja-se BADIOU, Alain, Sujeito e infinito, filosofía e política. Acontecimiento. Buenos Aires, publicação coletiva "A pesar de todo" da Escuela Porteña, n. 5 , 1973. E também, Para uma nova teoría do sujeito, do mesmo autor.

4 Veja-se GRÉCO, Pierre. O Estruturalismo. Ciencias Humanas. Buenos Aires, CEAL, 1967.

5 Há pelo menos duas de suas obras que apontam nas direções aquí comentadas: The variations of Animals and Plants under Domestication, de1868, e também The Expressions of the Emotions in Man and Animals, de 1872.

6 É plausível pensar que esta inquietação darwiniana tem sua origem nas preocupações e na obra de seu avô Erasmus (1731-1802), médico, naturalista e poeta inglês que sempre oscilou nos limites entre a ciência e a metafísica, tentando explicar as relações entre a permanência e as mudanças no campo biológico.

7 Note-se que, neste aspecto, tanto Lacan quanto Freud chegam bem mais longe que J.Piaget no que se refere aos determinantes do pensamento no sujeito, já que J. Piaget considera a herança somente nos seu desdobramentos de geral e específica. Veja-se novamente PIAGET, Jean (1969). Biología y Conocimiento, op. cit.

8 Veja-se CAMPBELL, Joseph (1993). El héroe de las mil caras. Psicoanálisis del mito. México, Fondo de Cultura Económica [ 1949]. E do mesmo autor, Las máscaras de Dios. Madrid, Alianza Editorial, 1991.

${ }^{9}$ Caso relatado fragmentarmente pelo Dr. Jean Bergès em seminário proferido em Buenos Aires, em 1984. Não é um caso de exceção já que ele responde à dinâmica frequente do ato criminoso praticado por psicóticos.

10 Ou bem da colagem do olho do outro no olho próprio, na formação esquizofrênica. Lembre-se, como exemplo, $\mathrm{o}$ ato de arrancar os próprios olhos praticado pela personagem do filme "Betty Blue". Ou quando a cena interditada fica colada nos próprios olhos, no caso do pesadelo que revela o autoengano do neurótico, na metáfora clássica de Édipo furando seus olhos. 
11 É necessário fazermos notar que o conceito de simbolização ao qual estamos nos referindo é próprio da psicanálise, e se diferencia marcadamente do conceito de simbolização proposto por Jean Piaget.

12 Ver LACAN, Jacques. Las psicosis, Seminário 3, op.cit, p. 216 e seguintes.

13 Considerando a questão de um modo mais estrito, nem sempre que aparece a erótica nas psicoses ela tem um caráter regressivo. Há momentos em que tais manifestações constituem tentativas de penetrar no mundo adulto cavando um lugar de reconhecimento de seu ato (sexual) no discurso social. Por sinal, a forclusão da lei simbólica, devido à oclusão da Funçao Paterna, devolve violentamente esses atos - produzidos inicialmente como uma tentativa simbólica - a uma dimensão puramente real, o que retorna o gozo às suas formas primodiais, ou seja novamente infantís. Talvez isso explique parcialmente a cara de satisfação, ou bem de tranqüilidade beatífica, que se observa em psicóticos, quando são punidos jurídicamente, após terem cometido atos que conseguiram horrorizar a seus semelhantes. Tratar-se-ía ali de um certo sucesso na tentativa de conseguir um estatuto simbólico para seu ato.

13 JERUSALINSKY, Alfredo. Traumas de Adolescência. In:Vários (1997). Adolescência, entre o passado e o futuro. Porto Alegre, Artes e Ofícios.

14 Neste ponto tomamos como referência a vasta experiência desenvolvida neste sentido por nosso já falecido colega Dr. Paulo C. Brandão, que costumava dizer que o verdadeiro limite da clínica ou da escola, quando trabalhamos com crianças gravemente perturbadas, não são suas paredes mas o bairro. Tomando o bairro, é claro, como circunscrição discursiva da cultura.

15 Referimo-nos aqui aos autônimos, ou seja aos significantes que geram seu próprio sentido sem depender dos outros sgnificantes para estabelecer sua significação 